\title{
IPARI TERMÉK- ÉS FORMATERVEZŐ MÉRNÖKI SZAK
}

\author{
Dömötör Csaba \\ egyetemi docens, Miskolci Egyetem, Gép-és Terméktervezési Intézet \\ 3515 Miskolc, Miskolc-Egyetemváros,e-mail: machdcs@uni-miskolc.hu
}

\begin{abstract}
Absztrakt
A Miskolci Egyetem Gépészmérnöki és Informatikai Kara nagy hangsúlyt fektet a differenciált képzésre, mely egyrészt lefedi az ipari igényeket, másrészt ésszerü határokon belül igazodik a hallgatók érdeklödési köréhez és igényeihez is. Ezen szemlélet nyomán indult el a 1996/97-es tanévben az osztatlan képzésen belül választható termékmérnöki szakirány, majd az bolognai folyamat során megvalósitott kétszintü képzésben az immár önálló Ipari termék- és formatervezö alapszak. Ez a cikk a szak múltját, jelenét és jövőjét kivánja röviden bemutatni.
\end{abstract}

Kulcsszavak: termékmérnök, formatervezö szak, képzési struktúra

\begin{abstract}
Faculty of Mechanical Engineering and Informatics at University of Miskolc places great emphasis on differentiated education, which covers both industrial needs and students' interests and needs within reasonable limits. This approach led to the start of the 1996/97 academic year as an optional product designer major within the undivided training program, followed by the Bologna Process two-level training in the now Industrial Design Engineering Bachelor's degree. This article is intended to briefly describe the past, present and future of this program.
\end{abstract}

Keywords: Product designer, Industrial design engineering, training structure

\section{Bevezetés}

A Miskolci Egyetem Gépészmérnöki és Informatikai Karának Gép- és Terméktervezési Intézete gondozza az Ipari termék- és formatervező alapszakos képzést. Az önálló alapképzési (BSc) szak előzménye a 1996-ban még az osztatlan képzés keretein belül indított termékmérnök szakirány, mely a 3 éves mérnöki alapképzést követően a 2 éves szakirányú képzés keretében adott választási alternatívát azon hallgatók részére, akik érdeklődtek a fogyasztóközpontú terméktervezés iránt. Az eredeti termékmérnöki szakirány meghatározó tárgyai tervezéselmélet, számítógéppel segített tervezés, modellezés, anyagismeret és alapvető közgazdasági ismeretek köré csoportosultak. A főbb tantárgyak: A design elemei, Számitógépes géptervezés, Formatan, Marketing, Készségfejlesztö technikák, Terméklogisztika, Innovációs menedzsment, Ergonómia, Szindinamika, Müszaki akusztika, Nemfémes anyagok, Termékfejlesztés alapjai voltak. Ezen tantárgyak, illetve ismeretcsoportok az Ipari termék- és formatervező alapszak esetében is megmaradtak, hiszen mindkét esetben mérnöki oklevelet adó képzésről beszélünk. A korábbi szakirány és a későbbi alapszak beindulása Dr. Péter József áldozatos munkája nélkül nem valósulhatott volna meg. 


\section{Alapszak indulása}

\subsection{Akkreditációs előírások}

A korábbi egyetemi diplomával ellentétben a kétszintü képzés során indított Ipari termék- és formatervezö alapképzési szak önálló képzési struktúrával rendelkezik, vagyis nem a gépészmérnöki alapszak hoz kapcsolódó specializációról van szó. A 7 szemeszter minden féléve egyedi, az Ipari termék- és formatervező szak akkreditációjához kapcsolódó Képzési és Kimenetei Követelményekben meghatározott arányban tartalmazza az elöírt tudományágakhoz és szakterületekhez kötődő ismereteket (1. táblázat).

1. táblázat. Képzési és Kimenetei Követelményekben elöirt kreditszámok

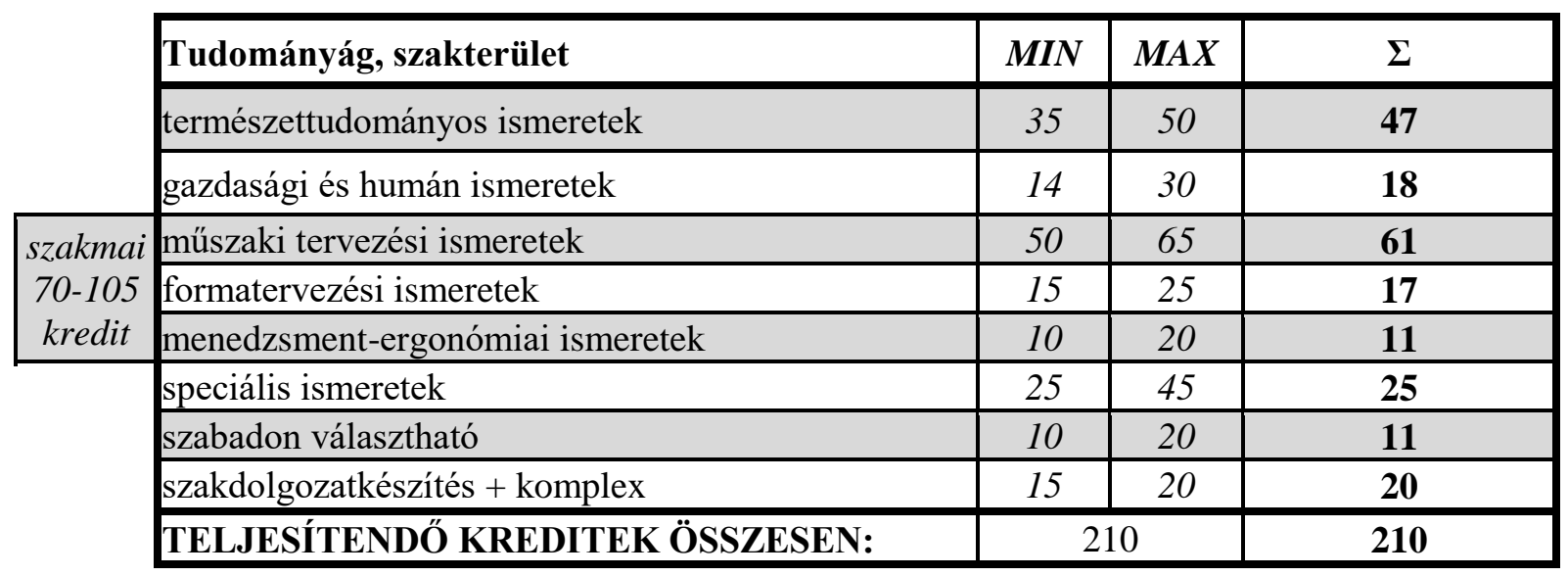

\subsection{Mérföldkövek}

A szak indításának egyik legfontosabb feltétele 2007-es intézményi akkreditáció volt, amit követően a szak 2008-ban elöször indulhatott el. A szakra jelenleg államilag finanszírozott és költségtérítéses formában is lehet jelentkezni, emellett a Gépészmérnöki és Informatikai Kar számos partnere támogatja a duális képzési formát is, mely 2016-tól elérhető. A Gép- és Terméktervezési Intézet a szak gondozása során olyan feltételeknek tett eleget, mellyel 2015-ben elnyerte az Akkreditált Kiváló Tehetségpont címet [4]. (1. ábra)

\subsection{Az alapszak által elérni kívánt tanulmányi kimenetek}

A szakon végzettek képesek a hatékony piaci válaszadásra, alkalmasak a termékek fejlesztésére az esztétikum, a használat, a gyártás, a környezet, a forgalmazás és a gazdaságosság szem előtt tartásával, vállalkozások és vállalatok keretein belül. Müszaki, esztétikai, humán, valamint gazdasági ismereteik és készségeik birtokában a termékfejlesztés valamennyi fázisában alkalmazhatók. Alkalmasak az alkotó, az irányított vagy önálló feladatmegoldásra, a szervező vagy irányító munkára. 


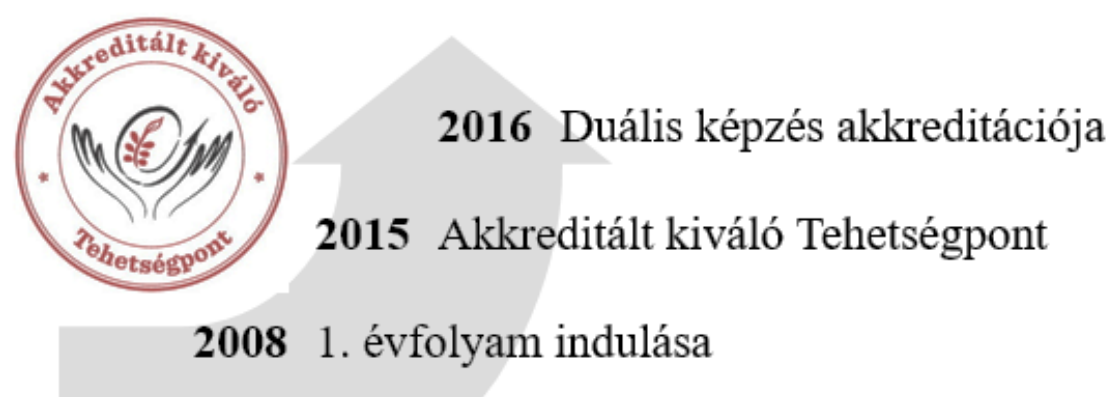

2007 Akkreditációs eljárás

\section{1. ábra. Mérföldkövek az Ipari termék- és formatervezö szak történetében}

Ismerik a termékfejlesztés fázisait, a termékfejlesztéshez szükséges tárgyi, szervezeti és emberi forrásokat. A végzettek képesek a szükség és a lehetőség felismerésére, az ötletek és az elképzelések összegyüjtésére, a problémák megértésére, vázlatok készítésére, a megoldásra, a dokumentálására és a prezentálásra szakértő és nem hozzáértő közönség számára, hazai és nemzetközi környezetben. Képesek termékeket tervezni, a rajzi kompetenciák birtokában a fejlesztés korai és későbbi szakaszában virtuálisan megjeleníteni, a tartalom és a forma összhangját megteremteni, tudományterületek eredményeit integrálni, esztétikai, használati, piaci, kivitelezhetőségi, emberi és környezeti szempontokat figyelembe venni. Képesek funkcióban és változatokban gondolkodni, értékelni és választani, a tárgyat konkretizálni, dokumentálni, virtuális vagy valóságos modell segítségével bemutatni. Képesek egy tervezési projekt kezdeményezésére és összeállítására, az egyén és a csoport feladatainak megosztására, összehangolására, hazai és nemzetközi környezetben. Képesek ismereteik bővítésére, itthon a mesterképzésünkben vagy külföldön további magasabb szintü tanulmányok folytatására.

\section{Képzés során hallgatott tárgyak}

Az Ipari termék- és formatervező szak tantárgyi tematikája Miskolci Egyetem Gépészmérnöki és Informatikai Karán folyó gépészmérnöki alapképzést kiindulásként véve lett kialakítva.

A szak akkreditációjához kapcsolódó Képzési és Kimenetei Követelmények betartása mellett figyelembe kellett venni a rendelkezésre álló erőforrásokat és azt is, hogy a kialakított tantervi háló a Miskolci Egyetemen folyó mérnökképzés kiemelkedő múltját és hagyományait kövesse. Ebben a képzésben specializációkat nem indítunk. A 2. ábra a képzés aktuális struktúráját szemeszterekre bontva mutatja be. A világosabb kerettel jelölt tantárgyak sok esetben nevükben is, de tartalmukat tekintve mindenképpen szoros egyezést mutatnak a gépészmérnöki alapképzés, illetve géptervező specializáció tantárgyaival, melyeket a Gép- és Terméktervezési Intézet gondoz. A sötétebb keret az Ipari termékés formatervező szak szintén intézetünk által oktatott speciális tantárgyait jelöli, melyekből láthatóan minden félévre besoroltunk néhányat. Összességében elmondható, hogy ezzel a konkrét tartalommal kizárólag a Miskolci Egyetemen találkozhatnak az Ipari termék- és formatervező alapszakos hallgatók. 


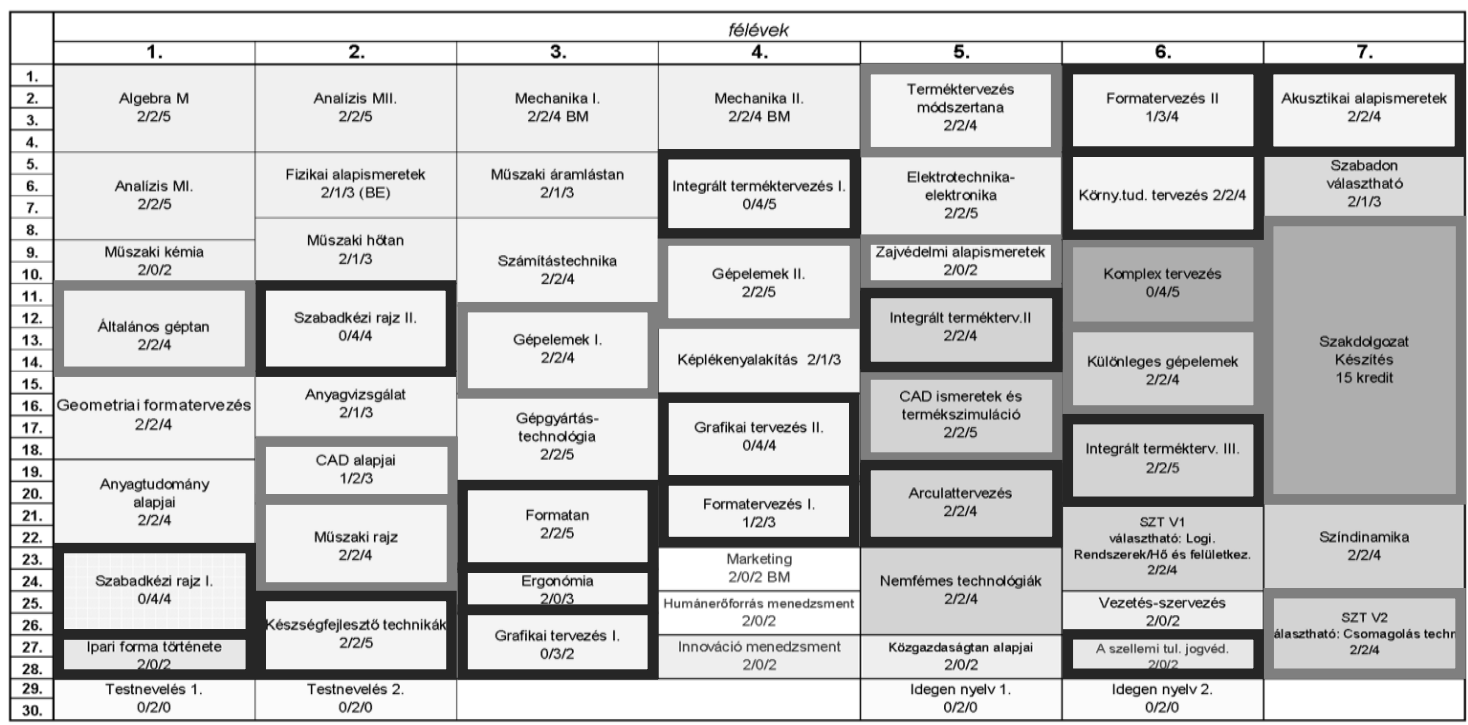

2. ábra. Tantervi háló féléves bontásban

\section{Magyarországi képzési helyek}

Magyarországon összesen 5 felsőoktatási intézmény hirdet meg évről-évre Ipari termék- és formatervező alapszakot, melyek regionális elhelyezkedését a 3. ábrán bemutatott térkép szemlélteti. Az ábrán balról jobbra haladva ezen intézmények képzési struktúrája és profilja alapján felsorolásszerủen megnevezhetőek hasonlóságok és különbségek a Miskolci Egyetem képzéséhez képest.:

- Nyugat-magyarországi Egyetem, Simonyi Károly Müszaki, Faanyagtudományi és Művészeti Kar (SOPRON)

A fó profil a faipar. Választható specializációk: Bútortervező; Termékmenedzsment; Terméktervezés; rendhagyó különlegesség, hogy az 5.félévtől Szombathelyen Egészségipari terméktervező specializáción is tanulhatnak az ide jelentkezők

- Pécsi Tudományegyetem, Müszaki és Informatikai Kar (PÉCS)

Fő profil az építészet köré csoportosul. Nincsenek specializációk. A képzésben építész, belsőépítész, környezettervező müvészek, tanárok is részt vesznek. Itt is jellemzők a faipari ismeretek.

- Budapesti Múszaki Egyetem, Gépészmérnöki Kar (BUDAPEST)

Szintén gépészmérnöki profil a kiindulási alap. Nincsenek specializációk, de választható ismeretkörök vannak: terméktervezés, termékmenedzsment, formatervezés.

- Óbudai Egyetem, Rejtő Sándor Könnyüipari és Környezetmérnöki Kar (BUDAPEST)

Fő profil a textilipar. Választható specializációk: Öltözéktervezés és kiegészítők; Enteriőrtervezés és textil; Csomagolástervezés. 


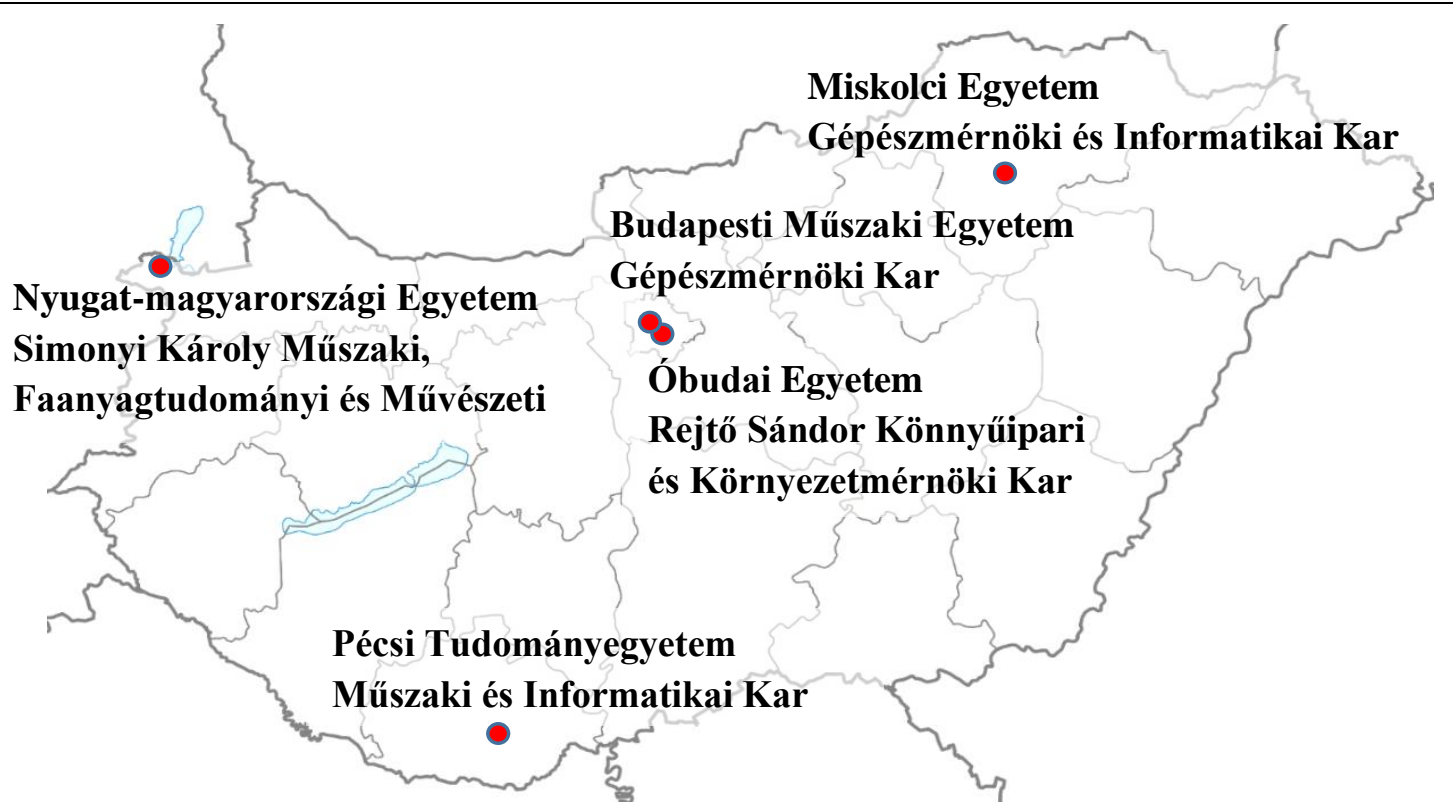

3. ábra. Ipari termék- és formatervezö alapszakot oktató intézmények Magyarországon

\section{Oktatási statisztika}

A szaknak szomorú statisztikai adata, hogy voltak olyan évek, amikor a felvételt nyertek alacsony létszáma miatt az Ipari termék- és formatervező alapszakot sajnos nem tudtuk elindítani. Az ilyen kimaradt évfolyamoknak kihatása van mind az előző években indított, mind pedig a későbbiekben indítandó évfolyamok fenntartására is. A 2. táblázatból és a hozzá kapcsolódó diagramból szembetűnő, hogy a szakra jelentkezők összlétszáma alapvetően sosem volt alacsony, viszont az első helyen hozzánk jelentkezők ezek közt mégis kevesen voltak.

A szak be nem indulásának okait keresve átalakítottuk az alkalmassági vizsga feladatait és beiktattunk egy személyes elbeszélgetést is a jelentkezőkkel, hogy jobban megismerjük a motivációjukat és preferenciáikat. Ezekből kiderült, hogy a hozzánk jelentkezők korábban nem mindig voltak teljesen tisztában a szak mérnöki oldalának hangsúlyos jellegével, illetve magasabb szintű (alkotó)múvészi fejlődést vártak a szaktól. Ezt a hiányos ismereteken alapuló félreértést egy a szakról szóló és a korábbinál informatívabb honlappal, facebook oldal indításával és a célközönség egyéb csatornákon való elérésével igyekeztünk orvosolni. Jelenleg egy lassú növekedés megindulása tapasztalható, amit további hirdetésekkel fogunk erősíteni. Ennek megfelelően a Miskolci Egyetem nyílt napjain mindig indítunk kifejezetten Ipari termék- és formatervező programot, hogy a középiskolás korosztály, a szülők és tanárok felé is tudatosítsuk a szak létezését. Ennek szintén jó eszköze volt a Miskolci Galériában megrendezett kiállítás is, melynek ötletgazdája, kurátora és rendezője Dr. Kavecsánszki Gyula volt. Dr. Dömötör Csaba szakfelelősként koordinálta a kiállítási anyag létrejöttét, amihez a Gép- és Terméktervezési Intézet munkatársainak, valamint volt és jelenlegi hallgatóinak kreatív munkája is nélkülözhetetlen volt. A kiállításon Miskolc város közönsége az Ipari termék- és formatervező alapszak kiemelkedő hallgatói munkái mellett megismerkedhetett a szakhoz kötődő hazai és nemzetközi intézeti projektekkel, versenyekkel és pályamunkákkal is. 
2. táblázat. Oktatási és kimeneti statisztika az Ipari termék- és formatervezö alapszakon

\begin{tabular}{|l|c|c|c|c|c|c|c|c|c|c|c|c|}
\hline \multicolumn{1}{|c|}{ Évek } & $\mathbf{2 0 0 8}$ & $\mathbf{2 0 0 9}$ & $\mathbf{2 0 1 0}$ & $\mathbf{2 0 1 1}$ & $\mathbf{2 0 1 2}$ & $\mathbf{2 0 1 3}$ & $\mathbf{2 0 1 4}$ & $\mathbf{2 0 1 5}$ & $\mathbf{2 0 1 6}$ & $\mathbf{2 0 1 7}$ & $\mathbf{2 0 1 8}$ & $\mathbf{2 0 1 9}$ \\
\hline Jelentkezők & 17 & 51 & 63 & 68 & 54 & 46 & 40 & 44 & 31 & 29 & 23 & 31 \\
\hline Felvett hallgatók & $\mathbf{1 6}$ & $\mathbf{1 7}$ & $\mathbf{1 8}$ & $\mathbf{1 9}$ & $\mathbf{1 9}$ & - & - & $\mathbf{9}$ & - & - & $\mathbf{6}$ & $\mathbf{7}$ \\
\hline Államvizsgázók & - & - & - & - & 8 & 9 & 11 & 17 & 11 & 5 & 4 & 4 \\
\hline Diplomát szerzett & - & - & - & - & 8 & 6 & 6 & 14 & 11 & 5 & 4 & 4 \\
\hline
\end{tabular}

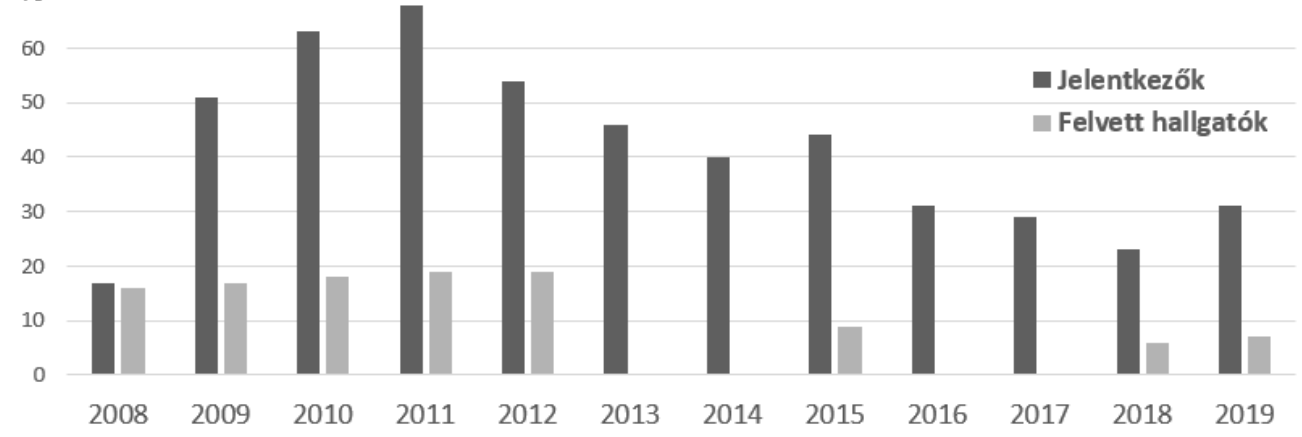

\section{Összefoglalás}

Összességében elmondható, hogy az Ipari termék- és formatervező alapszaknak sikerült egy jól kialakított tantárgyi tematikát és megfelelő infrastrukturális hátteret létrehoznunk. A piaci igények és az ipar visszajelzései is azt igazolják, hogy érdemes és szükséges a szakba energiát fektetni és így piacképes tudással rendelkező ipari termék- és formatervező mérnököket képezni a régióban.

\section{Köszönetnyilvánítás}

A cikkben ismertetett kutató munka az EFOP-3.6.1-16-2016-00011 jelü „Fiatalodó és Megújuló Egyetem - Innovatív Tudásváros - a Miskolci Egyetem intelligens szakosodást szolgáló intézményi fejlesztése" projekt részeként - a Széchenyi 2020 keretében - az Európai Unió támogatásával, az Európai Szociális Alap társfinanszírozásával valósul meg.

\section{Irodalom}

[1] Az Ipari termék- és formatervező mérnöki alapképzési szak képzési és kimeneti követelményei, 2016

[2] Az Ipari termék- és formatervező mérnöki alapszak belső értékelése, Miskolci Egyetem, 2018

[3] Dömötör, Cs.: Ipari termék- és formatervező mérnök hallgatók kiállításának szervezési tapasztalatai, GÉP 2018/4., ISSN 0016-8572, pp.13-16.

[4] Döbröczöni, Á., Kavecsánszky, Gy.: A Miskolci Egyetem Gépészmérnöki és Informatikai Kar Gép- és Terméktervezési Intézet Tehetségpontja; Tehetség: előnyök és hátrányok metszéspontján: a Nemzeti Tehetség Program és a tehetségesítés esélyei Északkelet-Magyarországon, Miskolc, 2014. ISBN 978-963-358-052-3, pp.124-130. 